\section{Joint and soft tissue injection}

Joint and soft tissue injection: injecting with confidence, Trevor Silver. pp vi +90 , illustrated. Radcliffe Medical Press Ltd, Oxford, 1996. £19.95, hardback.

The objective of this book is to provide the reader with confidence in joint and soft tissue injections. The book is written by a general practitioner for general practitioners but is also useful for trainees in rheumatology and general internal medicine.

There are two chapters covering general principles and medicolegal issues, and then seven chapters covering a major region each shoulder, wrist and hand, elbow, hip and thigh, knee, ankle and foot and spine. For each region there is a description of the functional anatomy, presentation and diagnosis of common problems. The technique for injection is then described. The volume is nicely illustrated with paired line drawings and clinical photographs showing local anatomy and injection site.

The volume is comprehensive and some conditions would not frequently be encountered in general practice. This book should certainly provide the reader with confidence in injection technique but should be used in conjunction with practical tuition from an experienced injector.

Trainees in rheumatology and internal medicine (together with experienced consultants) will find this a useful volume which compares well in quality and price with other books on the same topic. I would recommend it to those wishing to improve their injecting skills. The book should be readily available in clinics and surgeries where injections are regularly performed.

RA WATTS

Department of Rheumatology, Ipswich Hospital NHS Trust, Ipswich IP4 5PD, UK

\section{Human molecular genetics}

HLA and MHC. Genes, molecules and function, M Browning, A McMichael, eds. pp xvii +438 , illustrated. BIOS Scientific Publishers Ltd, Oxford, 1996. $£ 75.00$, hardback.

This book is the latest in a series of titles on human molecular genetics and is a welcome addition for students of medicine with an interest in the pathophysiology of disease. Following key discoveries in the early 1970 s of immune response genes and the link between HLA B27 and ankylosing spondylitis, this volume reflects progress over 25 years which has led to current understanding of the major histocompatibility complex (MHC) which spans 4 megabases of DNA-1\% of the genome - and includes at least 200 genes. The editors' approach rightly emphasises an essential physiological function of the MHC as a molecular apparatus which presents peptide ligands, ie, antigens, to $\mathrm{T}$ cells. Chapters follow seamlessly with comprehensive coverage of evolutionary aspects, gene organisation and regulation, cell biology, protein structure, polymorphism, peptide presentation and immune responses, mechanisms of disease associations, and allorecognition. It is remarkable that 'DNA typing' based on known nucleotide sequences is now almost routine methodology for laboratory detection of HLA alleles.

I found this a very approachable book. The editors are to be congratulated on achieving a coherent style, drawing as they do on expert contributors worldwide, and their thoughtful introduction succinctly highlights advances in the field. It will become the text for specialist practitioners and research students but the general reader should not be deterred - even if you read only the introduction and view the colour plates, you will be fascinated by the MHC.

RMR BARNES Royal Liverpool University Hospital, Liverpool L7 8XP, UK

\section{Paediatric emergencies}

What to do in a paediatric emergency, Ian Higginson, David Montgomery, Phil Munro. pp 48, illustrated. BMJ Publishing Group, London, 1996. £12.95, paperback.

There are a number of texts dealing with acute presentations in paediatrics and the major part of the text in such books deals with situations where a history and examination are possible. This book deals with the emergency situations where there is no time for such subtleties and care must be delivered immediately and appropriately. The guide contains straightforward protocols and procedures for use in such situations as trauma, choking, shock, asthma and coma. The guidelines on trauma management are particularly clear and easy to understand for non-surgeons and are based on the recommendations of the UK Advanced Life Support Group. Its aim, as the authors state, is to make important information readily accessible and it does achieve this well. Thoughtfully the booklet is ring-bound so that it stays open when put down.

The book could be used for training purposes and it would be reasonable to keep a copy in receiving and emergency rooms, intensive care units and on resuscitation trolleys. At several points in the text one is asked to seek 'expert advice'. It would be important, if this book were to be used as a principle source of emergency information, to annotate it with the contact details of such experts. Perhaps in future editions, space could be set aside for this. Ask your resuscitation committee and training officer to have a look at a copy.

$$
\text { S RYAN }
$$

Liverpool Women's Hospital, Liverpool L8 7SS, UK

\section{Medical meanings}

Medical meanings: a glossary of word origins, Haubrich WS, $253 \mathrm{pp}$. American College of Physicians, Philadelphia, 1997. Price not given.
Did you known that the word nicotine was derived from a French ambassador to Portugal? Or that the Latin word for sausage became botulism? The word sarcoma is from the Greek root sarco or flesh plus -oma, a fleshy tumour. From the same Greek root comes sarcasm, an utterance intended to cut the flesh; and sarcophagus, a box or container intended 'to swallow the flesh', that is, a coffin. On the other hand, the word liver is derived from the verb to live from the AngloSaxon lifer or the German leben. Semen is from the Latin word seed or germ so disseminate literally means to 'scatter seed'.

This and much more can be found in Professor Haubrich's excellent new glossary of words. $\mathrm{He}$ is a Californian gastroenterologist, who is also a co-author of Bockus' Gastroenterology. He has analysed over 3000 medical and related terms in a lively witty style. You may choose to use it as a dictionary but it is more than that for many of the entries tell fascinating stories. This makes it a treasure-trove of information surrounding the medical terms that we use every day. For example, ambulance comes from the French and began as hôpital ambulant, literally a walking hospital. During Napoleon's campaigns, to bring medical aid to soldiers in the field, portable units were devised that contained dressings and medicines and also provided for evacuation of the wounded. Cold turkey is vernacular for the total, abrupt cessation of a drug, especially a narcotic. The expression alludes to the gooseflesh appearance of the skin of addicts withdrawing from opiate addiction. The nodular appearance is that of the skin of unplucked poultry. Rhinorrhoea is a highfalutin way of describing a running nose (rhino from the Greek rhinos for nose and rhoia, a flowing). Spine comes from the Latin spina, a thorn or prickly bush, or the protuberances of vertebrae which resemble one.

Our 18th century Samuel Johnson is clearly a hero of the author who often quotes him. When a knowledgeable reader discovered an error in Johnson's 'Dictionary of the english language' he asked "Tell me, $\mathrm{Dr}$ Johnson, how could you have made such a mistake?" to which Johnson replied "Ignorance, madam, pure ignorance". Dr Haubrich warns that this would be his reply if anyone finds an error in this splendid thesaurosis (treasure trove) of his.

The book is highly recommended for junior doctors to get one over their chiefs and vice-versa; for nurses and paramedics so that they known better; and for all students who are curious to learn more.

\section{DG JAMES Royal Free Hospital, London NW3, UK}

\section{Medical training}

Learning medicine 1997. An informal guide to a career in medicine, $P$ Richards. pp 119, illustrated. BMJ Publishing Group, London, 1996. £8.95, paperback

This small paperback is the 13th in line from the author since the volume's debut in 1983 . 
It is comprehensive, taking the reader through the process of becoming a doctor from trying to analyse why we choose medicine (unsuccessfully) through to an outline of training and examinations for the postgraduate specialties.

I did, however, find the writing style rather heavy, bordering on the pedantic. The accounts of student life were stodgy and read more like the offerings for a GCSE essay than a vibrant account of life as a medic - even with its downside. While reference was made to the widespread changes in undergraduate learning throughout the country, the author could have expanded on this as, arguably, along with choosing a conducive environment, the way in which students 'learn medicine' is the most important decision to make - whether the traditional large lecture or the smaller problem-based tutorial system. I had other more trivial objections - my Scottish surgical colleagues would not like being referred to as 'Doctor', - they are definitely 'Mister' - (or in rarer cases 'Miss') whereas it is the Scottish gynaecologists who maintain their hardwon title; I did not recognise the ward-round with the retinue of juniors as described by Prof Richards - such things I thought had long disappeared with the reduction in junior doctor's hours - but maybe things are different in London!

Having said that, the book contains much useful information and is well worth reading by all prospective medical students, their parents and their teachers.

A GARDEN

Department of Obstetrics E Gynaecology, The University of Liverpool, Liverpool L69 3BX, UK

\section{The internet}

Medical information on the internet. A guide for health professionals, R Kiley. pp $x+133$, illustrated. Churchill Livingstone, London, 1996. $£ 16.95$, paperback

I rarely read every word when asked to review a book as some of them can be very long and tedious. In this case, however, being a relative newcomer to the internet, I decided I should read the entire book, and surprisingly I greatly enjoyed it. There are many useful features to tell you how to go about getting started in the internet, and I found it well put together and certainly for a relative novice a most useful introduction. Previously I have had to rely heavily on my sons at university who are much more computer-literate than I am, but I now feel that, at least as far as surfing the internet is concerned, or crawling the web, that I am able to compete. I would therefore recommend this book.

A MORRIS

Royal Liverpool University Hospital, Liverpool L7 8XP, UK

\section{Evidence-based medicine}

How to practice \& teach EBM, DL Sackett, et al. pp xii+250. illustrated. Churchill Livingstone, London, 1997. $£ 14.99$, paperback

The back cover of this handy little book poses four questions. Do you want to integrate the best available evidence with your clinical expertise? Do you worry that sometimes you don't? Do you want to get better at turning clinical problems into answerable questions? Do you want to enhance your ability to apply and teach evidence-based medicine in your everyday practice - in the clinic and the bedside?

If you answered yes to any of these then you will probably find this book useful. It is well referenced and the reader is guided through the text by a series of marginal icons. There is an excellent section on formulating answerable questions. The second section deals with searching for the best evidence. For some this will be the most useful section of the book, since it introduces a number of sources which have become important over the last few years. The authors give a great deal of help on how to use the internet and how to construct a useful Medline search. Subsequent sections cover appraising the evidence, deciding whether to apply it and evaluating the outcomes.

Medical students will find the book useful, especially the sections on formulating questions and searching for and appraising evidence. Junior doctors will find the sections on application and evaluation useful, and probably make most use of the five helpful prompt cards. More established clinicians and teachers will find this book both stimulating and useful. The authors have a web-page at URL http://cebm.jr2.ox.ac.uk

CM TAYLOR Faculty of Medicine Physiological Laboratory Liverpool L69 3BX, UK 